\title{
上䅡洞に発生した血管線維腫症例
}

中村 雅一・増田 成夫

近藤 玲子・川端五十鈴

\section{Angiofibroma of the Maxillary Sinus; A Case Report}

\author{
Masaichi Nakamura, Shigeo Masuda, \\ Reiko Kondo and Isuzu Kawabata \\ (Saitama Medical Center, Saitama Medical College)
}

\begin{abstract}
An 18-year-old boy visited our clinic complaining of painful swelling of the right cheek. CT scan and angiograms revealed a hypervascular lesion in the right maxillary sinus. The tumor was removed surgically under general anesthesia. Microscopic examination revealed histologic features compatible with angiofibroma. The reported cases of extranasopharyngeal angiofibroma are reviewed, and the pathogenesis, clinical features and treatment are discussed.
\end{abstract}

Key words: angiofibroma, benign tumor, maxillary sinus, epistaxis

はじめに

血管線維腫は若年男子に好発する良性腫瘍で, 主として鼻咽腔に生じ, 鼻咽腔以外の部位に原 発した報告例は稀である。私共は最近男子で上 顎洞に原発したと考えられる血管線維腫の一例 を経験したので，その概要を報告するととあに， 若干の文献的考察を加えた.

\section{症例}

患者 : ○湗 $\bigcirc$ 男, 18歳, 男性.

主訴：右煩部腫脹，鼻閉.

既往歴・家族歴：特記すべきことなし.

現病歴：昭和63年 3 月頃より右鼻閉, 鼻漏が 出現したが放置した８月25日に右煩部腫脹， 疼痛，発熱が掞てり，近医受診し抗生物質招よ び消炎鎮痛剂の投与受けたが，軽快しないため 当科紹介され，9月 1 日当科初診となる.

初診時全身所見：身長 $180 \mathrm{~cm}$, 体重 $60 \mathrm{~kg}$ で
体格栄養状態と屯良好な男子である.

一般血液検査では, 貧血や白血球増多はなく, 血清生化学も正常值であった．血沈 $29 \mathrm{~mm} / \mathrm{h}$, CRP 陽性，梅毒血清反応陰性，HB 抗原陰性で あった，尿検查，胸部 X線検査，心電図にも異 常所見はみられなかった。

初診時局所所見：右下眼瞼から煩部にかけて 腫脹，圧痛が認められた。右眼球は軽度上転し ていたが，複視は認められなかった，右鼻腔内 は，下鼻甲介が肥厚し，下鼻道側壁が鼻中隔側 に突出していた。硬口蓋粘膜は右半分が白っぽ く変色しており，知覚の低下がみとめられた。 顎下部や頸部のリンパ節は触知せず，上咽頭を はじめ他の耳鼻咽喉科領域に異常所見は認めら れなかった。

単純X線検査：節骨洞，前頭洞にび慢性の陰 影が認められ，右上顎洞では外側壁，内側壁に 
骨破壊が疑われる骨壁の菲薄化像を呈していた (図 1).

$\mathrm{CT}$ 検査：右上顎洞内には不均一に造影され る陰影が認められた，上顎洞骨壁は洞内より外 方に向かって圧排されているように菲薄化し， 球状に拡大していた。外側壁では骨が欠損して いる所見であった（図 2 ).

次に下鼻道側壁より右上䫑洞穿刺を施行した ところ, 穿刺部位より出血が多く認められたが, 膿は吸引できなかった。出血は圧迫により止血 できた。上顎洞穿刺で得られた血液の細胞診検 査では血球成分のみであり, 腫瘍細胞は認めら れなかった。

血管造影検査：上顎洞穿刺で出血が多かった ことより，血管性の病変を疑い外頸動脈および 内頸動脈血管造影㭘査を施行した. 上顎洞の上 部に造影剂の貯留を認めたが，顎動脈その他の
血管の明らかな拡張や変位はなかった（図 3 ). 以上の所見より血管性の腫瘍を疑い，入院の うえ10月 5 日に全身麻酔下に腫瘍摘出術を施行 した。

手術所見：まず右側外頸動脈をクリッピング した後, 歯肉部に切開を置き, 犬歯窩を露出し た．犬歯窩は一部骨壁が欠損していて腫湯が露 出していた (図 4). 犬歯窩の残存している骨を 鉗除した後, 腫瘍が易出血性であったためオキ シセル綿を腫瘍と骨壁との間に挿入するように して, 上顎洞より剝離し摘出した。腫瘍は軟ら かく一塊として摘出するととはできず，小片に 分けて摘出した. 眼窩下壁とやや強く癒着がみ られたが，骨壁より剝離は可能であった，上顎 洞骨壁は, 菲薄化しているものの, 前壁以外は 骨が欠損している部分はなく CT で示されたと おり球状に拡大していた，腫瘍をすべて切り除

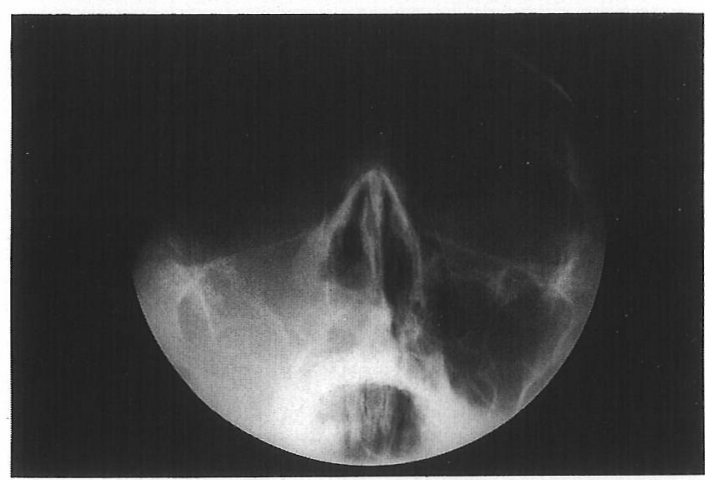

図 1 単純X線所見 右上顎洞の陰影を示す.

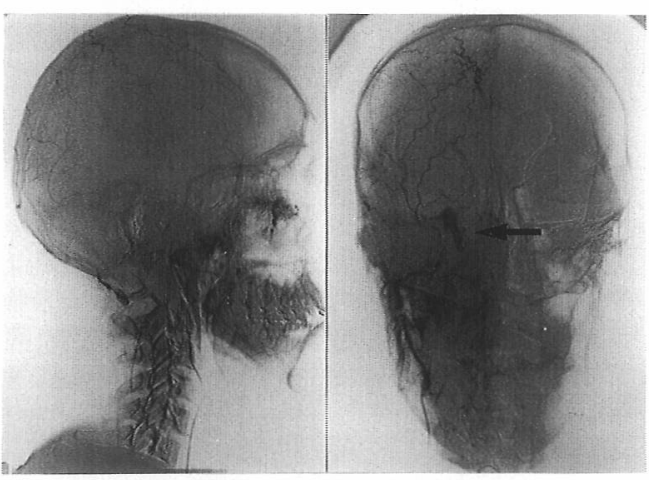

図 3 頸動脈造影所見

右上顎洞上部に造影剂の貯留を認める。

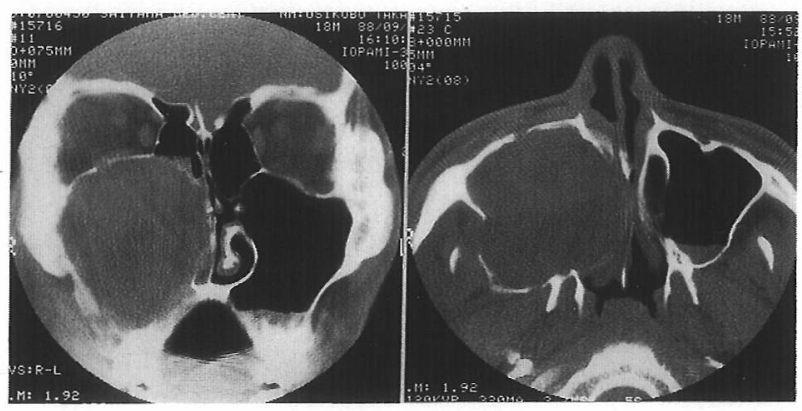

図2 $\mathrm{CT}$ 像

右上顎洞は球状に拡大し, 骨壁の菲薄化を認める. 
くと，上顎洞壁からの出血はほとんどなくなり， 腫瘍への栄養血管ははっきりしなかった，歯肉 切開部を開放創としたまま手術を終了した。術 中の出血量は $1400 \mathrm{cc}$ で, $800 \mathrm{cc}$ の輸血をおこな った.

病理組織学的所見 : 摘出した標本の大部分は 壊死組織を伴った密な線維性の洀痕様組織であ

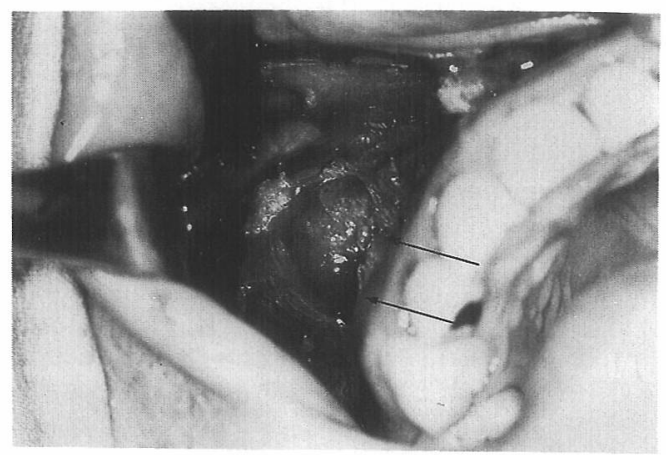

図 4 手術所見

上顎洞前壁に骨欠損が認められる。

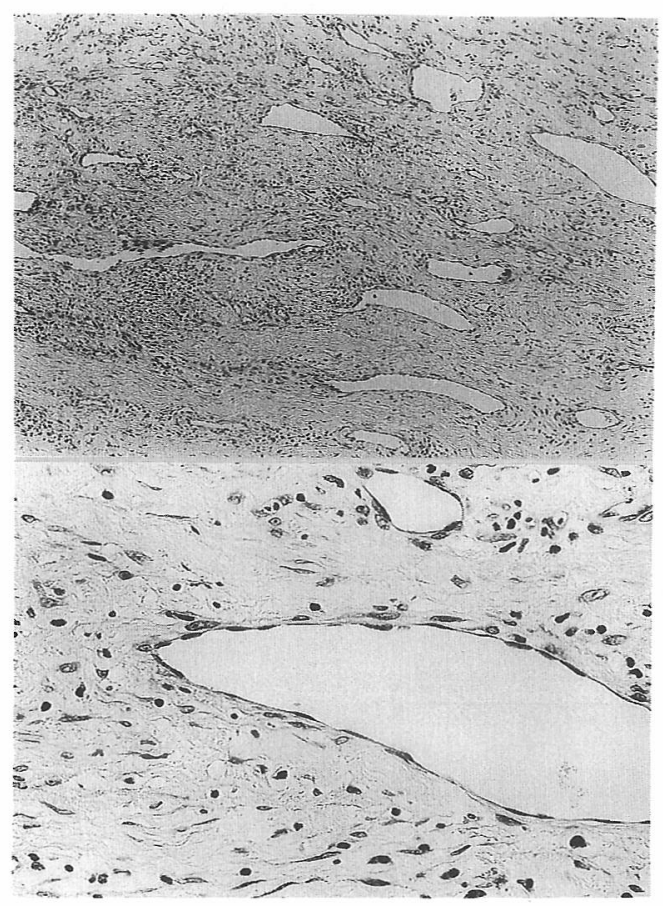

図 5 病理組織所見

昖張した血管が多数存在する結合織の増生（上）があ り，血管壁は一層の扁平な内皮細胞よりなる（下）.
った。一部に強い増生を示す線維組織中に，一 層の内皮細胞からなる血管腔が多数認められ， 血管線維腫の像を呈するすのが認められた（図 5 ).したがって，血管線維腫を母組織とし，上 顎洞内に出血をきたしたため臨床的に血瘤腫之 呼ばれている状態になったと考えられる。

術後経過: 術後 1 年を経過した現在, 腫湯の 再発は認められていない。右眼球は術前には上 転位にあったが，術後約 4 力月までにほぼ正常 位に復帰し，複視や眼球運動障害の発生はなか った，右下鼻道側壁の突出も徐々に小さくなり， 現在では右の鼻閉は消失している.

\section{考察}

血管線維腫は比較的稀な良性腫痬で，多くの あのは思春期の男子の上咽頭に発生する。組織 学的には良性でありながら易出血性で周囲組織 に浸潤性に進展するため臨床的に治療が困難で ある場合が多い、今回私共は若年男子の上顎洞 に原発した大きな血管線維腫で手術的に摘出し 得た興味ある症例を経験したので，文献を引用 しながら 2 の の点について考察を加えた。

上咽頭血管線維腫について：上咽頭血管線維 腫の発生頻度は報告者により差があるが，外来 患者総数の 5000～50000 人に 1 程度と考えられ

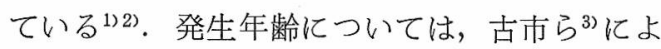
れば本邦で報告された 262 例中16〜25歳のもの が171例であり, 平均は21.1歳で, 30 歳以上は 稀であるとしている。しかし岩佐ら は40歳代 以後にあうひとつの小さいピークが存在してい て，若年者に発生するものとは発生原因が異な るのではないかと述べている，男女比は $241 ：$ 18 (不明 3 ) であり ${ }^{3)}$,女性には稀である.Capps ら5)は女性には血管線維腫は存在せず，報告さ れている症例は pedunculated fibromaまたは polyp であると述べており，女性患者の発生に は否定的であるが，電子顕微鏡による形態学的 観察では，女性に発生したあの之男性に発生し たものとは微細構造は同じであるという報告も あり ${ }^{6}$ ，女性に屯稀ではあるが，血管線維腫は存 在すると思われる. 
上咽頭以外の血管線維腫について：上咽頭以 外の頭頸部領域に発生した報告例は少なく，外 国ではAliら7により37例の集計が認められ，本 邦では木村ら ${ }^{8)}$, 広田ら ${ }^{9)}$ の集計に大河内ら ${ }^{2)}$ の 症例を合わせると，報告例は34例になる。乙れ らの報告例に Juul ら ${ }^{10)}$ の症例を加えた70例(水 流，小倉らの報告例が重複しているので）につ いて発生部位を検討してみると，上顎洞21例， 穊骨洞 5 例, 蝶形骨洞 3 例, 鼻腔 17 例之約 3 分 の 2 が鼻副鼻腔に発生している. 食道, 気管に それぞれ 1 例ずつ報告がみられる以外はすべて 頭頸部領域に認められている.

上顎洞原発の血管線維腫について：検索した 限りでは上顎洞に発生したものは本症例を含め

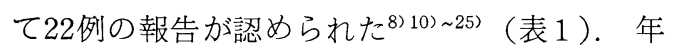
歯は50歳代が 3 症例みられるが，10歳代，20歳 代が中心で平均年齢は24.5歳であり, 年齿の分 布については上咽頭に発生するむのと同じ傾向
がみられる. 男女比は17：5 であり，上咽頭に 発生するあのより女性に多い傾向がある。また， 右側15例に対して, 左側 6 例と右に多く認めら れるが，その意義については不明である.

臨床症状は, 鼻出血, 鼻閉を主訴とすること が多いが，約半数の症例では煩部腫脹があり， その他眼球突出, 眼球の変位, 複視など眼症状 や側頭部痛が認められる。このような症状は上 顮腫瘍一般にみられる症状とほぼ同じである. そのため過去の報告例もほとんどが上顎腫瘍の 術前診断のもとに上顎洞開洞または鼻腔内ポリ 一プの生検が行われている. しかし，他の上顎 腫瘍に比べて, 鼻出血については出血量が多い 傾向があり，鼻腔内ポリープの生検や試験開洞 に際しても多量の出血が起こっている ${ }^{11) ~ 16) . ~}$ 本症例では試験開洞は行わなかったが上顎洞穿 刺にて出血が多く認められ，血管原性の腫瘍を 疑うきっかけとなった。

表 1 上顎洞に発生した血管線維腫報告例

\begin{tabular}{|c|c|c|c|c|c|}
\hline & 報 告 者 & 年歯 & 性 & 部位 & 症 \\
\hline 1 & 村山（1904） & 50 & M & 右 & 鼻閉, 煩部腫脹 \\
\hline 2 & 水流（1936） & 33 & $\mathrm{~F}$ & 右 & 鼻閉, 鼻出血, 煩部腫脹, 疼痛 \\
\hline 3 & Munson (1941) & 15 & M & 左 & 煩部腫脹，鼻出血 \\
\hline 4 & Alajmo ら (1961) & 6 & M & 右 & 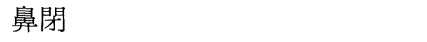 \\
\hline 5 & Alajmo ら (1961) & 58 & M & 右 & 煩部腫脹 \\
\hline 6 & Hora ら (1962) & 13 & M & 右 & 煩部腫脹，鼻出血，鼻閉 \\
\hline 7 & 小倉ら（1965） & 16 & M & 右 & 鼻出血，煩部腫脹 \\
\hline 8 & Stricker (1967) & 22 & M & 右 & 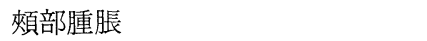 \\
\hline 9 & Maniglia ら (1969) & 15 & M & 右 & 鼻閉, 鼻出血, 頓部腫脹 \\
\hline 10 & Perko (1969) & 33 & $\mathrm{~F}$ & 右 & 歯痛 \\
\hline 11 & Pathak (1970) & 18 & M & 左 & 鼻出血，鼻閉 \\
\hline 12 & Chakrabarti ら (1973) & 17 & M & 右 & 鼻閉, 煩部腫脹, 鼻出血 \\
\hline 13 & Ryc (1973) & 17 & M & 左 & 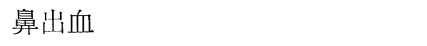 \\
\hline 14 & Ramanjaneyulu (1974) & 17 & M & 右 & 鼻閉，煩部腫脹 \\
\hline 15 & 野垣ら（1977） & 22 & M & 右 & 鼻閉, 視力低下, 眼球突出, 複視 \\
\hline 16 & $\| \quad(" 1)$ & 22 & M & 右 & 鼻出血，鼻閉 \\
\hline 17 & 菊地ら（1978） & 50 & M & & \\
\hline 18 & Juul ら (1982) & 27 & $\mathrm{~F}$ & 左 & 側頭部痛, 鼻閉 \\
\hline 19 & 白幡ら（1982） & 39 & $\mathrm{~F}$ & 左 & \\
\hline 20 & $\| \quad(" 1)$ & 29 & $\mathrm{~F}$ & 左 & \\
\hline 21 & 木村ら（1983） & 1 & M & 右 & 鼻閉, 鼻出血 \\
\hline 22 & 自験例 & 18 & M & 右 & 頓部腫脹, 鼻閉 \\
\hline
\end{tabular}


腫瘍の基部についてははっきり確認が出来な かったものが多いが，記載のあるあのについて は後壁8) 10>17) 18), 外側壁 ${ }^{13)}{ }^{15)}$, 後内側壁 ${ }^{16) 18) な と ゙ ~}$ の報告があり，後壁からの発生が多いようであ る。本症例については血管造影検査の所見と手 術時に上顎洞上壁部のみ瘾着が強かった点から 上顎洞上壁に基部があったと考えられる．腫瘍 は上顎洞に限局しているものから，篩骨洞 ${ }^{199}$, 蝶形骨洞 ${ }^{1118)}$ ，さらに後鼻孔を通って上咽頭 ${ }^{15)}$ にまで達するものなど様々の程度に進展したも のが報告されている.

血管線維腫の成因について：血管線維腫の発 生に関しては古来より多くの説があるが，未だ にはっきりしていない。蝶形骨体之後頭骨底部 の間に存在する胎生期の fibrocartilage ${ }^{26)}$, 上咽 頭後壁の骨膜 ${ }^{27)}$ ，頭蓋底付近の咽頭腱膜と口腔 咽頭筋膜の癒合によって形成される fascia basalis $^{28)}$ などの線維性組織に由来する腫瘍である という考えが古くからある。また， paragang lionic tissue に起源をむつ腫瘍であると述べて いるあのもある ${ }^{29)}$. 最近では口蓋骨の蝶形骨突 起と鋤骨が接している鼻腔天蓋の後側壁下の粘 膜下加発生すると考えられているようであ る ${ }^{30)}$. 血管線維腫の患者には性の発達が未熟な ものが認められるととから，性ホルモンが関与 している可能性を示唆するものもいる ${ }^{31)}$. ホル モンレセプターの検索によるとエストロゲンや プロゲステロンのレセプターは認められないが, 男性ホルモンに対するレセプターが存在し，血 管線維腫はアンドロゲン依存性と考えている報 告が多いようである ${ }^{32}$.

研究者の多くは真性腫瘍であると考えている が，一部には炎症あるいはアレルギーによる増 殖であり腫瘍ではないという考えあある。Osborn ${ }^{33)}$ は異常な血管が鼻腔内の組織にも認め られるととから vascular hamartoma であり， 微小血管の出血に続いて生じる修復機構により 肉芽組織の形成さらにひきつづいて線維組織の 形成がおこると推定している. Schiff ${ }^{34)}$ は上咽 頭の発達段階に鼻甲介の血管性組織の一部が,
いずれ骨膜へと発達する間葉組織へとりとまれ 発達したものであると考えている. Stiller ら ${ }^{35)}$ は血管線維腫の線維芽細胞の形態学的検討から, 真の腫瘍よりはむしろ反応性あるいは過形成性 の病変を支持する結果が得られたと述べている， 年路とともに自然退縮するあのがあるとともこ のような考えを支持している．今回私共の症例 からは発生因子を知りえる手掛かりは得られな かった。

治療について：血管線維腫の治療については, 手術療法, 放射線療法, 性ホルモン療法などが 行われてきた。しかし，放射線療法に関しては， かなり大量の線量を照射しなければ腫瘍の縮小, 消失は認められず，その結果周囲組織への重篤 な後遺症を併発したり，悪性腫瘍の発生の危険

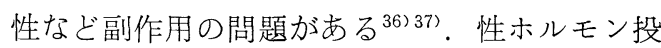
与については效果の点でいまだに評価が一定し ていない ${ }^{36)}$. したがって外科的摘出が第一選択 であり，全摘出が困難な場合や再発が認められ たときに放射線療法や性ホルモン療法が補助的 に行われるべきであるとされている ${ }^{14)}$. 鼻副鼻 腔に発生したものについては解剖学的位置のた め上咽頭に発生したものに比べ手術的に摘出で きているものが多い.しかし，症例により差は あるが，他の腫瘍に比べて出血が多くなるため 十分に視野をとって手術をするととが必要であ る. 最近では上咽頭の血管線維腫に対し超選択 的塞栓術施行後に手術を行ったという報告がさ れており ${ }^{32}{ }^{38)}$ ，手術中の出血に対して有効であ ると思われる。本症例については術前の血管造 影検査で造影剂の貯留が軽度で，サブトラクシ ョンをするまで眝留がはっきりしなかったため, 塞栓術を行わなかったが，行っていれば出血量 を減らすととが十分に期待できたと思われる。

\section{結語}

右上顎洞に原発した血管線維腫の 1 例を報告 した。症例は18歳男性で右煩部腫脹を主訴に来 院し，全身麻酔下に腫瘍を摘出した。鼻咽腔以 外に原発した血管線維腫は稀であり, 病像, 成 因，治療などについて文献的考察を加えた。 
本論文の要旨は第28回日本鼻科学会(平成元年10月) でロ演した。

\section{文献}

1 ）志水雄輔, 藤谷哲造, 中川 璇, 他：上咽頭線維 腫. 耳喉 $45: 889 \sim 900,1973$.

2 ）大河内幸男, 小針仁美, 大梘好正, 他 : 鼻腔血管 線維腫の 4 症例. 耳鼻臨床 補 $10 ： 133 \sim 140$, 1987.

3 ）古市暢夫, 金森邦彦, 大藤周彦, 他：巨大な鼻咽 腔血管線維腫の 2 症例と本邦報告例についての文 献的考察. 耳喉 $44: 875 \sim 890,1972$.

4 ）岩佐英之, 神尾友和 : 鼻咽腔血管線維腫の診断に 関する一知見. 日耳鼻 $82: 663 \sim 669,1979$.

5) Capps FCW, Irvine $G$ and Timmis P : Four recent cases of juvenile fibroangioma of the postnasal space. J Laryngol Otol 75 : 924 931, 1961.

6 ) Svoboda DJ and Kirchner F : Ultrastructure of nasopharyngeal angiofibromas. Cancer $19: 1949$ 〜1962, 1966.

7) Ali S and Jones WI : Clinical records extranasopharyngeal angiofibromas (sex incidence and age distribution). J Laryngol Otol $96: 559 \sim 565$, 1982.

8）木村 裕, 長船宏隆, 勝村久子, 他：幼児の上顎 洞血管線維腫の一症例. 日鼻会誌 $26: 135 \sim 136$, 1987.

9 ）広田敦子, 辺土名仁, 苦瓜知彦, 他：鼻腔より発 生した若年性血管線維腫の 1 例. 耳喉頭頸 61 : 477〜 482， 1989.

10) Juul A, Larsen $K$ and Illum $P$ : Angiofibroma of maxillary antrum. Arch Otorhinolaryngol 236 : 135 138, 1982.

11) Munson FT : Angiofibroma of the left maxillary sinus. Ann Otol Rhinol 50 : 561 569, 1941.

12) Alajmo $\mathbf{E}$ and Fini-Storchi $\mathrm{O}$ : Ilfibroangioma primitivo del le nasali e dei seni paranasali. Boll Mal Orecch 79: 217〜240, 1961.

13）小倉義郎，伏見直哉，大上 浩，他：上顎洞内に 原発した若年性血管線維腫の 1 治験例. 日耳鼻 $68: 1234 \sim 1240,1965$.

14) Maniglia AJ, Mazzarella LA, Minkowitz S, et al : Maxillary sinus angiofibroma treated with cryosurgery. Arch Otolaryngol $89: 527 \sim 532$, 1969.

15) Pathak PN : Extranasopharyngeal juvenile angiofibroma-a case report-. J Laryngol Otol $84: 449 \sim 451,1970$.

16) Ramanjaneyulu $P$ : Juvenile fibroma of antral origin. Int Surg $59:$ 423 424, 1974.

17）村山政之助：上顎洞血管線維腫ノ一例. 大日耳鼻 12 : 346 356, 1906.

18) Chakrabarti RN, Venkataramaiah NR, Rao PRV, et al : Extranasopharyngeal juvenile angiofibroma-a case report-. Indian J Cancer $10: 471 \sim 474,1973$.

19) Hora JF and Brown AK : Paranasal juvenile angiofibroma. Arch Otolaryngol $76: 457 \sim 459$, 1962.

20）水流義雄 : 顔面二自潰セル鼻腔副鼻腔血瘤腫ノ一 例. 耳喉 $9: 316 \sim 318,1936$.

21) Stricker G : Ausgedehntes sklero sierendes Hämangiom der Nebenhöhlen und seine klinischen Komplikationen. Monatsschrift für ohrenheilkunde und laryngo-rhinologie $101: 271,1967$.

22) Perko M, Ueblinger E and Hjфrting-Hansen E : Nasopharyngeal angiofibroma of the maxilla ; report of case. J Oral Surg $27: 645 \sim 648,1969$.

23) Ryc K, Malicka K and Ksiazek J : Juvenile angiofibroma of maxillary sinus. Otolaryngol $\mathrm{Pol}$ $27: 543 \sim 545,1973$.

24）野垣俊幸, 前坂明男, 滝元 徹, 他：鼻腔および 上顎洞原発の若年性血管線維腫. 耳展 20:230 237, 1977.

25）白幡雄一, 児玉 実, 足川力雄 : 鼻科領域血管腫 の臨床像. 耳展 $21: 430 \sim 439,1978$.

26) Bensch H : Beiträge zur Beurtheilung der chirurgischen Behaudlung der Nasenrachenpolypen. E Morgenstern, Breslau, 1878.

27) Ringertz N : Juvenile nasal fibroma in pathology of malignant tumors arising in the nasal paranasal cavities and maxilla. Acta Otolaryngol Suppl $27:$ 158 161, 1938.

28) Brunner H : Nasopharyngeal fibroma. Ann Otol Rhinol Laryngol $51: 29 \sim 65,1942$.

29) Girgis IH and Fahmy SA : Nasopharyngeal fibroma; its histo-pathological nature. J Laryngol 
Otol $89:$ 1107 1123, 1973.

30) Harrison DFN : Juvenile postnasal angiofibroma; an evaluation. Clin Otolaryngol $1: 187 \sim$ 197, 1976.

31) Martin H, Ehrlich HE and Abels JC : Juvenile nasopharyngeal fibroma. Ann Surg 127 : 513 536, 1948.

32) Antonelli AR, Cappiello J and Lorenzo D : Diagnosis, staging, and treatment of juvenile nasopharyngeal angiofibroma. Laryngoscope $97: 1319 \sim$ 1325, 1987.

33) Osborn DA : The so-called juvenile angiofibroma of the nasopharynx. J Laryngol $73: 295 \sim 315$, 1959.

34) Schiff M: Juvenile nasopharyngeal angiofibroma. Laryngoscope 69 : 981 1016, 1959.

35) Stiller D, Katenkamp D and Küttner K : Cellu- lar differentiations and structural characteristics in nasopharyngeal angiofibromas. Virchows Arch [A] $371: 273 \sim 282,1976$.

36）竹林脩文, 屋敷建夫, 野田益弘, 他：若年性鼻咽 腔血管線維症例とその治療法の検討. 耳喉 44 : 201 208, 1972.

37) Chen KTK and Bauer FW : Sarcomatous transformation of nasopharyngeal angiofibroma. Cancer $49: 369 \sim 371,1982$.

38）田中佐一良, 栘田 耕, 滝元 徹, 他 : 塞栓術が 有効であった上咽頭血管線維腫例. 耳鼻臨床 80 : 115〜119, 1987.

$\left(\begin{array}{l}\text { 原稿受付 : 平成元年11月13日 } \\ \text { 原稿採択 : 平成元年11月 } 29 日 \\ \text { 別刷請求先 : 中村雅一 } \\ \text { T350 埼玉県川越市鴨田过道町1981 } \\ \text { 埼玉医科大学総合医療センター耳鼻咽喉科 }\end{array}\right)$

